\title{
Responsibility and Rights
}

\author{
Sergio Dellavalle*
}

(Received 24 June 2018; accepted 23 July 2018)

\begin{abstract}
A new era of responsibility seems poised to overshadow the human rights discourse in international law. On the one hand, introducing the perspective of responsibility must result in an added value when compared to the former predominant approach. In fact, some justifications are inconsistent, and the most radical interpretations jeopardize the very core of the modern theory of social and legal order-namely, the centrality of the individual. On the other hand, the incorporation of responsibility into the discourse on rights may help to overcome some of its most evident shortcomings. Nonetheless, despite some positive outcomes which the new attention on responsibility may bring about, the concept is flawed by at least two major deficits. First, the reference to responsibility tends to presuppose the possibility of taking the position of a privileged observer. This implicitly rejects the idea that the moral and legal community is essentially constituted by human individuals who freely recognize each other as equal members and rightful holders of entitlements. The second deficit is instead related to the intrinsically particularistic character of responsibility, which makes it rather difficult to apply to the field of international law and relations. An analysis shows that we are confronted with a conflict: while responsibility can, in fact, be assumed to bring an added value, the costs for this are exceedingly high, because they amount to no less than the abandonment of the core concept of modern moral and political philosophy. By recurring to the communicative paradigm of rationality and social order, a possible solution is outlined according to which responsibility is reinterpreted in the sense of a time, space, composition, and content-related expansion of mutual recognition.
\end{abstract}

Keywords: Autonomy; communication community; corporate social responsibility; discourse theory; duties; obligations; holism; individualism; paradigms of order; responsibility; responsibility to protect; human rights

\section{A. Introduction}

Are we entering the era of responsibility? ${ }^{1}$ Some scholars make this claim, arguing that the focus on responsibility is overshadowing the central position that the human rights discourse has claimed in post-nationalistic international law-also called humanitarian or cosmopolitan international law-for the last decades. ${ }^{2}$ At first, the assertion can be interpreted in two different

\footnotetext{
${ }^{*}$ Sergio Dellavalle is Professor of Public Law and State Theory at the University of Turin (Italy), Department of Law; senior research affiliate and co-director of the research project Paradigms of Public Order at the Max Planck Institute for Comparative Public Law and International Law, Heidelberg (Germany); associate member of the Cluster of Excellence Normative Orders at the University of Frankfurt (Germany); emails: sergio.dellavalle@unito.it; dellavalle@mpil.de.

${ }^{1}$ On the meaning of responsibility in international law, see James Crawford \& Jeremy Watkins, International Responsibility, in The Philosophy of International Law 283-98 (Samantha Besson \& John Tasioulas eds., Oxford Univ. Press 2010); Liam Murphy, International Responsibility, in The PhILOsophy OF InTERnATIONAL LAW 299-315 (Samantha Besson \& John Tasioulas eds., Oxford Univ. Press 2010); Volker Roeben, Responsibility in International Law, in 16 MAX PLANCK YEARBOOK OF United NATIONS LAW 99-158 (2012).

${ }^{2}$ For a presentation of the arguments in favor of the paradigmatic shift from rights to responsibility as the pivotal element of humanitarian or cosmopolitan law as well as of the scholarship supporting this claim, see Tomer Shadmy, The Rising of 
ways: one more radical and the other rather conciliatory. According to the first understanding, responsibility is going to replace the focus on human rights, while the second stresses only the necessity of an integration of the latter with the former. Anyway, the introduction of the perspective of responsibility should be justified as an added value if compared to the purely rightscentered discourse. In other words, it should bring an additional and significant element to support a correct use of theoretical and practical reason-in particular in the field of international law and relations - in comparison with the results that we can achieve by recurring only to the discourse on rights. The question regarding the added value of the reference to responsibility is stressed in the next Section. Although some justifications are inconsistent, and the most radical approach seems to question the very core of the modern theory of social and legal order-the need for individuals to be the center of society-, the proposal to incorporate responsibility into the discourse on human rights aims to work out what appears to be a weakness of the usual rightscentered approach. ${ }^{3}$

Even if we come to acknowledge that the reference to responsibility makes sense to the extent that it broadens the horizon of our use of practical reason and corrects some shortcomings of the rights-centered discourse, the application of responsibility continues to show at least two relevant deficits. The first regards its capacity to expand the use of practical reason insofar as it is connected to overcoming the idea of the moral and legal community. Such a community, in this instance, is one constituted by human individuals who are assumed to be able to articulate their claims in a propositional way and to freely recognize each other as equal rights holders. The second deficit, instead, is related to the intrinsically particularistic character of responsibility, which makes it rather difficult to apply to the field of international law and relations. Both problems are discussed in the third Section.

At the beginning of the fourth Section, we are confronted with a dilemma. On the one hand, if compared to the traditional human or fundamental rights discourses, responsibility seems to bring indeed an added value. On the other hand, this benefit is paid at a quite high price-namely with the abandonment of the core concept of modern moral and political philosophy, on which essential values such as democracy and human rights are grounded. Not to mention the inherent difficulty to adapt responsibility to the cosmopolitan context. In the fourth Section of the Article, I will outline a possible solution to the dilemma, in which responsibility is re-interpreted in the sense of an expansion - in time, space, composition, and content - of mutual recognition by recurring to the communicative paradigm of rationality and social order.

A short conclusion summarizes the results of the inquiry while outlining the reasons why the use of the concept of responsibility may nonetheless make sense under certain circumstances.

\section{B. Meanings of Responsibility}

At the very beginning of my analysis, two premises should be made. First, I do not address responsibility in this context as a concept which applies to the reflections on the accountability of one's own behavior regarding the accomplishment, or omission, of an action that is reasonably regarded as justified. ${ }^{4}$ In other words, the question which I will look into is not under which circumstances and to what extent I am to be held responsible-i.e., accountable-for doing or not doing something. Rather, my aim is to analyze responsibility as a notion located within the discourse on the uses of practical reason in a relational setting; in particular, as a form of justification of actions which may affect someone or something. Therefore, in the context of my inquiry, the question is whether responsibility for someone or something can be a justification for accomplishing or

Human Rights Responsibilities: R2P and CSR - Different Forms of the Same New Dialect (GlobalTrust Working Paper 6, 2016), https://papers.ssrn.com/sol3/papers.cfm?abstract_id=3047021.

${ }^{3}$ Eric A. Posner, The Twilight of Human Rights Law (Oxford Univ. Press, 2014).

${ }^{4}$ Joseph Raz, From Normativity to Responsibility (Oxford Univ. Press, 2012). 
omitting a certain action, beside or beyond the reference to rights which may be recognized to the addressee of the action. Thus, we could also say that the problem which I focus on here is more basic than the interpretation of responsibility as accountability or causation. First, it must be determined, in a relational setting, which action can, with good reason, be considered justified and whether the reference to what can be called responsibility-as a non-rights-related approach - can provide such a justification. Only then, in a second step, we can concentrate on the question of the individual accountability for performing or omitting the action.

The second premise refers to the meaning of the concept of responsibility if compared to those of duty and obligation. Each of these notions is employed in the scholarship with slightly-and sometimes even significantly-different connotations, so that a clarification regarding their use in this Article may be helpful. Throughout the Article, I use duty to describe what we mutually ought to do in order to implement the rights of others. On the contrary, responsibility is referred to forms of commitment to action which are not necessarily related to recognizing rights of the addressees of the action. In this sense, responsibility is centered on the subjective approach of the agent to the situation as well as on the specific context of the envisaged action and may be influenced by prudential choices and opportunities. Finally, obligation is used in its most general connotation, for example, as a self-imposed commitment to action, or as an external-more or less strictly binding - request to perform an action. Such commitments or requests, however, might originate from quite different sources of justification, such as agreements, customs, personal feelings of solidarity or responsibility towards individuals, social groups and communities, or, even, moral duties. Consequently, the reference to an obligation can indicate, in the following, an ought that derives from the acknowledgement of rights, so that the normative content of an obligation, in these circumstances, is essentially equivalent to that of a duty. Obligation, however, can also be referred to non-rights-related commitments or requests, such as those which are grounded on responsibility.

Under these conditions, the core of the question of responsibility as a justification of action is its possibility of being an alternative to the rights-centered discourse-or at least an integration of it. A problem arises immediately when we address the issue of the relationship between responsibility and rights - why should we leave the centrality of the human rights approach? Or, in a more concrete form, which is the advantage that we can draw from the introduction of the perspective of responsibility? In fact, if it is not to prove that responsibility helps us to understand better how we should act in the complex world of social interactions, there would be no justification for the introduction of a further concept. This would only make reality, as well as its comprehension, even messier and the sight more blurred. The answers that have been given to these questions can be led back to no less than nine main patterns. The first answer points out the need to overcome the one-sidedness of the discourse on rights, while underlining the dimension of obligations. ${ }^{5}$ The second interprets responsibility as a specific virtue, thus aiming at protecting and improving goods, and not at implementing rights. ${ }^{6}$ The third pattern maintains that responsibility safeguards the living conditions of human individuals who cannot propositionally claim their rights. ${ }^{7}$ The fourth interpretation considers responsibility with reference to human individuals and social groups, who or which, although in principle able to articulate propositionally their claims, are substantially hindered from doing this by unfavorable social and political conditions. ${ }^{8}$ The fifth answer appeals to responsibility in order to safeguard the interests of non-human individuals who are considered inherently incapable of asserting their rights and thus excluded from the community of the rights holders. ${ }^{9}$ According to the sixth pattern, responsibility is extended

\footnotetext{
${ }^{5}$ Infra Section B.I.

${ }^{6}$ Infra Section B.II.

${ }^{7}$ Infra Section B.III.

${ }^{8}$ Infra Section B.IV.

${ }^{9}$ Infra Section B.V.
} 
into the past as well as into the future, so as to protect the heritage of our ancestors and the living conditions of future generations. ${ }^{10}$ In the seventh interpretation, responsibility comes to the fore as the solution for the preservation of non-individual goods, such as the environment, the world of the living creatures, etc. ${ }^{11}$ The eighth answer stresses the superiority of the discourse on responsibility over the discourse on rights as regards the flexibility in the choice of instruments and forms of intervention for protection of the interests of stakeholders. ${ }^{12}$ The ninth and last pattern concentrates on the so-called Corporate Social Responsibility (CSR)-actions of corporate actors, especially when no explicit infringement of rights seems to be in place. ${ }^{13}$ Let us analyze each one of the patterns in a little bit more detail.

\section{Responsibility as the Antidote to the One-Sidedness of the Rights-Centered Discourse}

The first and most obvious criticism that can be raised against the human rights discourse focuses on its alleged one-sidedness. More concretely, the debate on rights would only draw attention to the entitlements of the individuals, with two possible negative consequences. On the one hand, from a strongly communitarian perspective, it would remove the individual obligations with regard to the wellbeing of the community. ${ }^{14}$ On the other hand, even if we cautiously recognize the superiority of individual priorities over the interests of the community, the one-sided rights-centered discourse would nevertheless run the risk of sidelining and underestimating the motivational conditions for the implementation of individual entitlements. ${ }^{15}$ As a reaction to this shortcoming, the discourse on responsibility would bring a more balanced approach into the debate. Indeed, the argument seems to be largely acceptable, yet, on closer inspection, it is not as valuable as it appears to be at first sight. In fact, a very influential strand of modern philosophy grounds the moral and legal community on the individuals as endowed with inherent rights, as well as with interests and the capacity of rational judgement as its core element. ${ }^{16}$ On that basis, the individuals - supposed to be originally free and equal - grant each other a set of essential rights as the formalization of the inescapable rules and principles of a social life based on mutual acknowledgement, autonomy, and legitimacy. ${ }^{17}$ As a result, not only the definition of rights and their protection are fundamental for the establishment of legitimate institutions, but it is also assumed that no obligations are given but those which correspond to the safeguard of related rights on the other side. Put differently, I have obligations-or, in an even more explicit sense, I have duties - to the extent that someone else is acknowledged as having corresponding rights. Moreover, obligations do not need any further form of specific motivation but the acknowledgement that the addressees of the action are endowed with rights. If we assume this point of view, insisting on the importance of responsibility as the driving force behind the fulfilling of obligations would only shift the perspective from the addressee of the action to the agent, without adding any new content. Going even a step further, we would have to admit that developing a specific discourse on responsibility would be almost redundant and actually devoid of real consistency. In fact, in a moral and legal community of free and equal people, we ought to act with responsibility

\footnotetext{
${ }^{10}$ Infra Section B.VI.

${ }^{11}$ Infra Section B.VII.

${ }^{12}$ Infra Section B.VIII.

${ }^{13}$ Infra Section B.IX.

${ }^{14}$ Mary Ann Glendon, Rights Talk: The Impoverishment of Political Discourse (Simon \& Schuster 1991); Arthur J. Dyck, Rethinking Rights and Responsibilities: The Moral Bonds of Community (Georgetown Univ. Press 2005).

${ }^{15}$ Shadmy, supra note 2.

${ }^{16}$ ImManUel Kant, Grundlegung zur Metaphysik der Sitten, in WerKaUsGabe Bd. VII, 9-102 (Wilhelm Weischedel ed., 1785); IMMANUEL KanT, Kritik der praktischen Vernunft, in WerKausgabe Bd. VII, 105-302 (Wilhelm Weischedel ed., 1785); Immanuel Kant, Die Metaphysik der Sitten, in Werkausgabe Bd. VIII, 309-634 (Wilhelm Weischedel ed., 1785).

${ }^{17}$ John Rawls, A Theory of Justice (The Belknap Press of Harvard. Univ. Press, 1999; $1^{\text {st }}$ ed. 1971); JÜrgEN Habermas,

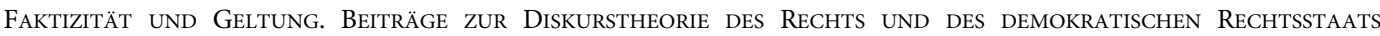
(Suhrkamp 1992); OtFried Höffe, Demokratie im Zeitalter der Globalisierung (Beck 2002).
} 
simply because we recognize that the counterparts are rights holders themselves. From the point of view of the moral agent, therefore, the recognition of rights must always correspond to the establishment of obligations, at least from the moment when we transform inherent but abstract individual rights into enforceable legal entitlements as a consequence of the implementation of the social contract derived from consent. For that reason, the recent tendency of an impoverished human rights discourse that aims almost exclusively at enforcing individual preferences, with little or no interest in even minimal standards of national or international social and ecological justice, should not be regarded as the coherent result of the intrinsic deficits of the human rights idea. ${ }^{18}$ Rather, it should be interpreted as pathological corruption within a context of unfettered selfishness. Nor is the present blindness of some advocates for the centrality of human rights towards the issue of economic inequality - which has been correctly criticized ${ }^{19}$ - to be justified on the basis of the assumption that rights are rooted in mutual recognition. On the contrary, it is instead arguable that it is precisely a correct understanding of the concept of mutual recognition that requires a substantial limitation of inequality. ${ }^{20}$

\section{Responsibility as a Virtue}

Yet, generally, the plea to draw more attention on responsibility means more than just the request to focus on the motivations of action. Rather, if taken seriously, it presupposes a deep-going paradigmatic shift in what we understand as the basis of the moral and legal community, therefore affecting the very fundament of our social interactions. According to this understanding, responsibility is a "virtue," 21 aiming at implementing goods, not at protecting rights. In other words, responsibility would be the attitude that we display when it comes to the realization and protection of values which are considered to be essential for a specific idea of the common good, ${ }^{22}$ such as a certain conception of what is thought to be a good way of life, a good society, or, more generally, a decent being-in-the-world. As a result, because responsibility according to this view is virtue and not rights-related, obligations must be identified which do not correspond to mirror-inverted rights, provided that the discourse on responsibility is to have some specific added value. Accordingly, we would have justifiable obligations towards someone or something who or which is not generally acknowledged as a rights holder-or, at least, not as a holder of entitlements on equal footing. ${ }^{23}$ But, what is the nature of such obligations? Two main characteristics stand out. First, if it is assumed that I have more obligations than those which I owe to the fellow humans or citizens who are regarded as rights holders, this implies necessarily that there must be an instance acting as a source of obligations beyond the individuals. Thus, we cannot but admit, in this case, that the whole of the social community-or its "holon"-must entail some added value when compared with the worth of the sum of its members. In fact, from the holistic point of view the social community is not only genetically located before their members; rather, it is also axiologically put above them. ${ }^{24}$ Yet, this assumption runs against the most fundamental tenet of

\footnotetext{
${ }^{18}$ Samuel Moyn, The Last Utopia (Belknap Press 2012); Samuel Moyn, Rights vs. Duties: Reclaiming Civic BALANCE (last visited July 14, 2018), http://bostonreview.net/books-ideas/samuel-moyn-rights-duties.

${ }^{19}$ Samuel Moyn, Not Enough: Human Rights in an Unequal World (Belknap Press 2018).

${ }^{20}$ See Habermas, supra note 17, at 151; Rawls, supra note 17, at 57, 263; Höffe, supra note 17, at 74.

${ }^{21}$ Garrath Williams, Responsibility as a Virtue, in Ethical Theory and Moral Practice, Vol. 11, 4, 455-70 (2008).

${ }^{22}$ Alasdair MacIntyre, After Virtue (Univ. of Notre Dame Press 1981); Alasdair MacIntyre, Is Patriotism a Virtue? 3-20 (March 26, 1984), https://mirror.explodie.org/Is\%20Patriotism\%20a\%20Virtue-1984.pdf.

${ }^{23}$ Yet, when entitlements are recognized by law only to some members of the society and not to all of them, we should speak of privileges, not of rights. Some privileges may be justified—for instance, those enjoyed by the members of parliaments—but they should always be strictly related to the function implemented by the privileged position, and only secondarily to the person who implements it. Furthermore, the function should be open, in principle, to all members of the social and political community and should be exercised in the exclusive interest of the community itself.

${ }^{24}$ Armin von Bogdandy \&amp; Sergio Dellavalle, Universalism Renewed. Habermas' Theory of International Order in Light of Competing Paradigms, 10 German L.J. 1, 5-29 (2009); Sergio Dellavalle, Dalla COMUNitÀ PARTICOLARE ALL'ORDINE
} 
modern society-namely, that the social community as a whole has its only justification in the safeguard of the entitlements of its members - and that it should not be seen as having a worth in itself which is not rooted in the value of the citizens or, more generally, of the human beings who constitute it. ${ }^{25}$ The second characteristic of non-rights-related obligations refers to the fact that, if I am supposed to have obligations towards someone regardless of the rights that we can mutually claim, then these obligations must be generated by the specific and privileged social position of that person. This guarantees that she or he stands out from the populace. As a result, obligations must be grounded not in mutual commitment, but in hardly justifiable hierarchy and social status, which-once again - goes counter to the social contract of democratic communities. According to the idea of the democratic social contract authority, starting from an original condition of equality, can be legitimated only through bottom-up deliberative procedures. ${ }^{26}$

To sum up, we can provisionally conclude that insisting on obligations beyond rights as the main task of the politics of responsibility is either one of two things: (1) devoid of specific contents, because it does not add anything new to the discourse, or (2) highly problematic to the extent that it implicitly suggests abandoning the idea of the moral and legal community as composed of free and equal rights holders. Yet, even if we do not choose to give up this conception, emphasizing responsibility could make sense insofar as it draws attention to the obligations that we have towards potential rights holders who, nevertheless, are not generally regarded as full members of that community. This approach characterizes four further meanings of responsibility.

\section{Responsibility Towards Immature or Impaired Human Beings}

In modern philosophy, belonging to the moral and legal community is considered to be depending on individuals being capable of claiming their rights and interests in a propositional way. In other words, to be members of that community, individuals must be able to articulate what one reasonably believes to be their entitlements and priorities by means of understandable utterances within an open and fair discourse. Putting it even more concretely, one must possess a sufficient awareness of oneself as well as of the other participants in the interaction, and he or she must be endowed with the capacity to speak. Under these premises, the personal autonomy that is expressed through my own claim for rights and defense of interests is transformed into a collective autonomy by implementing the conditions of a fair discursive interaction. Through the open-minded exchange of arguments on rights and interests, and the mutual recognition which is implied hereby, a society constitutes itself as a community of free and equal rights holders. Nonetheless, there are members of the human community, such as little children as well as persons affected by mental disability or dementia, who are unable to express their needs by understandable linguistic means. Intuitively, we perceive them as belonging to the community of the rights holders even if they cannot satisfy the criterion of being able to express themselves through meaningful propositions. On this basis, the concept of responsibility can be justifiably brought into play in order to describe the obligation according to which every one of those who can propositionally express claims has to safeguard also the rights of the fellow humans who cannot.

UNIVERSALE. VOL. I: I paradigmi storici, (ESI 2011); SERgIo Dellavalle, The Plurality of States and the World Order of Reason: On Hegel's Understanding of International Law and Relations, in SySTEM, ORdER, AND INTERNATIONAL LAW, 352-78 (Stefan Kadelbach, Thomas Kleinlein \& David Roth-Isigkeit eds., Oxford Univ. Press 2017).

${ }^{25}$ Thomas Hobbes, De Cive (Kessinger Publishing 2004) (1642); Thomas Hobbes, Leviathan, or the Matter, Form, and Power of a Commonwealth Ecclesiastical and Civil (CreateSpace 2011) (1651); John Locke, Two Treatises of GOVERnMent (Kessinger Publishing 2004) (1690); JEAN-JaCQUes Rousseau, DU CONTRACT SOCIAL, OU PRINCIPES DU DROIT POLITIQUE (Garnier-Flammarion 1966) (1762).

${ }^{26}$ Sergio Dellavalle, "From Above", Or "From the Bottom Up"? The Protection of Human Rights Between Descending and Ascending Interpretations, in Definition and Development of Human Rights and Popular Sovereignty in Europe, 91-113 (Council of Europe Publishing, 2011). 


\section{The Responsibility to Protect}

A similar understanding of responsibility distinguishes also its fourth application. The analogy consists, here, in the fact that the addressees of what we can define as "responsible actions" are generally recognized as rights holders. The difference, however, is that they are, in principle, perfectly capable of claiming their rights; there are no intrinsic reasons why they cannot express their preferences and interests. Nonetheless, they do not. This happens because of external impediments. This is the case of individuals, social groups, or entire nations, who or which are so oppressed that their voices are silenced. Their bodies and minds possess all instruments to articulate their position in the context of a debate on the definition of mutual entitlements and duties. Yet, they are hindered by political tyranny or social exploitation to an extent that they are made speechless. No forum is given to their voices, with the result that they cannot participate in the deliberative process which is due to set the rules of a dignified human interaction. Thus, we-and, with us, all those who are allowed to actively participate in the debate on generally acknowledged rights and duties - cannot hear them and cannot know precisely which their claims and priorities are. Nonetheless, we can reasonably infer what those claims and priorities are likely to be-not on the basis of unproven assumptions, but of falsifiable arguments derived from as wide a debate as possible. If applied to the field of international law, this approach leads precisely to what has been called the responsibility to protect, namely the duty to safeguard the rights of those who are not allowed to enter any forum - either national or international — and, thus, have no means to defend their rightful entitlements and dignity. ${ }^{27}$

\section{Responsibility Towards Non-Human Living Beings}

In both former circumstances, responsibility comes into play in order to protect rights and dignity of human individuals who are assumed to be part of the moral and legal community, but, for various reasons, cannot participate in the discourse, based on mutual recognition, which should determine the contents of the generally acknowledged entitlements. But there is another group of living beings which deserves to be treated with due responsibility - although they have never been and will never be, not even potentially, fully-fledged members of that community. This is the case of non-human animals, or at least of those belonging to some species among them. The difference from the forms of responsibility which involve human beings is that non-human animals are excluded from the outset from any form of participation in the discursive interaction that constitutes the moral and legal community of the free and equal. The issue here is that-unlike human beings who could participate in the interaction, but are excluded from the active involvement because of age, disease or external impediment-non-human animals do not even have the most abstract potentiality to enter the discursive interaction as a result of the barrier between species and of different, largely incommensurable forms of communication. Yet, we do bear responsibility towards them-though the reasons must be sought elsewhere. Indeed, the division line that was created to separate humans, on the one hand, from non-human animals without any distinction, on the other, is becoming more and more untenable due to a growing number of evidences which unequivocally point in the opposite direction. Some animals, for example, are capable of behaviors which show signs of germinal morality, or display emotional reactions which are comparable to human feelings, such as love and empathy. ${ }^{28}$ Some may be regarded

\footnotetext{
${ }^{27}$ Alain Pellet, The Definition of Responsibility in International Law, in THE LAW OF INTERNATIONAL RESPONSIBILITY 3-16 (James Crawford, Alain Pellet \& Simon Olleson eds., Oxford Univ. 2010); Eyal Benvenisti, Sovereigns as Trustees of Humanity: On the Accountability of States to Foreign Stakeholders, 107 AM. J. INT'L L. 295-333 (2013); Michael Byers, International Law and the Responsibility to Protect, in Sovereignty, Statehood, and State Responsibility 23-50 (Christine Chinkin \& Freya Baetens eds., Cambridge Univ. Press 2015); The Oxford Handbook of the Responsibility to Protect (Alex Bellamy \& Tim Dunne eds., Oxford Univ. Press 2016).

${ }^{28}$ Frans De WaAl, Good Natured (Harvard Univ. Press $7^{\text {th }}$ ed. 2003).
} 
as "subject-of-a-life," ${ }^{29}$ and, in any case, many are sentient beings who can feel pain and suffer. ${ }^{30}$ Thus, because a continuum can be detected in many fields of experience between human and nonhuman animals, the latter ones should be regarded as moral patients who can be severely affected by our actions. Under these premises, acting with responsibility is not an option, but downright an obligation.

\section{Responsibility Towards Past and Future Generations}

So far, all moral patients towards whom we have to exercise responsibility are presently living beings. Yet, we have also cases in which responsibility is to apply to individuals or groups belonging to the past or to the future. More concretely, we have inherited works of art and landscapes from past generations, and we have to pass them on to the future generations-along with a natural environment in which decent living conditions are possible. In these circumstances, though, the responsibility we owe-unlike the approach that I will shortly present under Section B.VII-is not toward non-human addressees, like non-living artworks, landscapes or the physical environment. Nor is it toward the living biosphere as such. Rather, responsibility is directed toward non-actually living human beings, in particular towards those who created the world of culture into which we were born, and are worthy of respect for the good they have done, as well as toward those who will live after us and deserve to experience natural and spiritual conditions which, at least, should not be worse-and possibly better-than ours. ${ }^{31}$

\section{Addressees of Responsibility as Non-Individual Entities}

The four former meanings are characterized by responsibility being addressed to entities which bear the essential traits of individuality. This further understanding is different insofar as the addressees of responsibility are entities without individual features, such as nature as a whole, the environment, ${ }^{32}$ the world of the living creatures, ${ }^{33}$ and a specific cultural tradition or language. Unlike the understanding of responsibility under Section B.VI, responsible actions are not directed toward individuals who, in the future, may have the right to enjoy these realities, or depend on them for a decent life. Rather, the elements of the real world which are supposed to have an inherent value are ontologized and, thus, made independent of individuals as rights holders. The hereby intended meaning of responsibility implies a no less radical, though different, departure from the traditional understanding of the just use of practical reason as related to a community of individuals based on mutual recognition than the approach described under Section B.II. The difference is that under Section B.II, the addressee of responsibility is always a concrete social and political community, whereas under Section B.VII it is rather the substantiation of an abstract idea, which can correspond to a form of social interaction-a specific language or culture, for instance-but also to non-social entities, the holon of nature or of the living world. Both cases, however, are characterized by the same missing component, namely mutual recognition between the bearers of responsibility and its addressees. ${ }^{34}$ As a result, if we accept the premises developed according to the understandings of responsibility laid down under

\footnotetext{
${ }^{29}$ Tom Regan, The Case for Animal Rights (University of California Press 2004).

${ }^{30}$ Peter Singer, Animal Liberation (HarperCollins 2009); Gary L. Francione, Introduction to Animal Rights (Temple Univ. Press 2000); Gary L. Francione, Animals as Persons (Columbia Univ. Press 2008); Elisa Aaltola, ANIMAL SufFErING (Palgrave Macmillan 2012).

${ }^{31}$ Jens Saugstad, Moral Responsibility Towards Future Generations of People, Lecture at University of Oslo (June 17, 1994), http://folk.uio.no/jenssa/Future\%20Generations.htm.

${ }^{32}$ Hans Jonas, Das Prinzip Verantwortung, (Suhrkamp 1984).

${ }^{33}$ Paul W. Taylor, The Ethics of Respect for Nature, 3 ENVTL. ETHICs 197-218 (1981).

${ }^{34}$ At first glance, mutual recognition seems to be missing also in the meanings of responsibility analyzed in the Sections B.III, B.IV, B.V and B.VI. On closer examination, however, a kind of implicit, expanded or analogous reciprocal acknowledgement can be assumed in those cases. See infra Section D.
} 
Sections B.II and B.VII, we would be required to fulfill obligations and, therefore, to put in place morally just actions in a threefold non-mutual context: (1) toward holders of public power who are supposed to be in a somehow different-and more privileged-social position than the rest of the citizenry - as under Section B.II; (2) toward the whole of the community which is assumed to be axiologically superior to its individual members - as under Section B.II as well; and (3) toward social and natural entities which are, in principle, incapable of whatsoever form of recognition-as under Section B.VII.

\section{Responsibility as the Guarantee for Context-Related Flexibility}

An obligation, if it is meant as a duty, entails a very limited and strictly regulated range of flexibility. Indeed, what we are obliged to do as a duty is quite precisely determined by the content of the right which constitutes its counterpart after having been acknowledged on a reciprocal basis by the members of the moral and legal community. The only form of elasticity in the implementation of an obligation is justified, here, by the sometimes inevitable balancing between rights-and between duties corresponding to them-when rights come into conflict with each other. Also, the incomplete fulfillment of a duty towards a rights holder is acceptable in these cases only if the lack of any limitation would produce an even more serious infringement of another right, and under the condition that the essential content of the limited right is preserved. ${ }^{35}$ Yet, there might be situations in which a more nuanced approach seems to be the most reasonable solution. Sometimes prudence appears to be a more valuable and viable way to address a problem than insisting on a deontological stance. Resorting to responsibility-and not to sheer duty-has been proposed as the key to resolve these forms of impasse, because responsibility "is a dynamic and ongoing mission, based upon relationships and involving broad discretion."36

\section{Corporate Social Responsibility}

The economy - in particular, the ways in which the production of goods, the markets and the financial transactions are organized — can have a relevant and sometimes devastating impact on the ecological and social equilibrium. In the last few decades, the situation has become even more dramatic because of the economic globalization. Faced with an evident incapacity or unwillingness of states and international organizations to address the issue with the necessary vigor by means of public law, private economic actors - in particular "the most exposed businesses"- "have responded with voluntary initiatives." ${ }^{37}$ More concretely, they have adopted-acting alone or in cooperation-codes of self-regulation which aim at contributing "to the social good beyond what is legally mandated to them." ${ }^{38}$ This phenomenon, CSR, represents a further example of use of the concept of responsibility in the sense of an instrument which is not compelling and as a justification of action which refrains from any reference to duties. Reservations can be hardly expressed against CSR insofar as it steps in for a lack of necessary interventions by the public power, or it delivers a surplus of guarantees if compared to the standards specified by law. The problem arises, however, if it is claimed that CSR should - and could-downright replace the intervention of public powers and that it could fulfill the tasks that are generally attributed to the law. This claim is not convincing for two main reasons. The first is the evident risk that CSR turns out to be a mere choosing and picking by the corporate actors, limiting the intervention to the fields where costs are low and media impact is high. The second reason for skepticism is even more substantial; if the contents of the standards introduced by the CSR codes are to be understood as having general validity, then they should also be

\footnotetext{
${ }^{35}$ The provision that "in no case may the essence of a basic right be affected"-also called Wesensgehaltsgarantie-is enshrined in the Art. 19, para. 2, of the Basic Law of the Federal Republic of Germany. See Peter Häberle, Die Wesensgehaltsgarantie Des Art. 19 Abs. 2 Grundgesetz (Müller 1983).

${ }^{36}$ See Shadmy, supra note 2 , at 4 .

${ }^{37}$ Radu Mareş, The Dynamics of Corporate Social Responsibilities 2 (Martinus Nijhoff 2008).

${ }^{38}$ Id. at 1 .
} 
generally protected by law and not left to the arbitrary initiative of private actors. Leaving fundamental obligations to the generosity and arbitrariness of private actors downgrades responsibility to a form of more or less enlightened paternalism and, lastly, to a kind of selfishness in disguise.

\section{Particularism and the Perspective of the Privileged Observer in the Concept of Responsibility}

To sum up the results of the inquiry into the different meanings of responsibility, we can conclude that the introduction of the concept, at least as regards some of its applications, turns out to be rather useless or unconvincing. On the one hand, it is useless when responsibility ends up being nothing more than a different point of view on the obligations which we have towards rights holders and a distinct way of describing them, but without any additional content. ${ }^{39}$ It is unconvincing or even worrying, on the other hand, when it heads to a paternalistic approach to social obligations, or the reintroduction of responsibility becomes a kind of camouflage to hide a backwards-oriented rediscovery of an organic understanding of society. ${ }^{40}$ In the other circumstances, however, the reference to responsibility seems to correct some evident weaknesses of the traditional idea of the moral and legal community, as composed of human individuals who are able to mutually acknowledge one another and to express their claims through meaningful utterances. In fact, it would broaden the horizon of our obligations, extending them also to addressees who cannot explicitly express their claims, but have nevertheless to be regarded as rightful beneficiaries of our interventions.

Therefore, the appeal to responsibility appears to make some sense indeed. Yet, the price that we would have to pay if the introduction of responsibility would sideline the rights-centered discourse and the idea of the moral and legal community based on self-conscious mutual recognition is anything but cheap. The problem is twofold. The first issue involves what we would risk losing by giving up the centrality of the mutual recognition of rational individuals as the fundament of our obligations. ${ }^{41}$ On the contrary, the second focuses on the intrinsic difficulties that the use of the concept of responsibility meets when it is applied to non-particularistic contexts. ${ }^{42}$

\section{Responsibility and the Overcoming of the Reflexive Community of Rights Holders}

If we look at the history of political ideas, we have to acknowledge that obligations have been rarely interpreted in a horizontal way. To the contrary, they were mostly understood from a vertical perspective. In other words, obligations were likely to receive top-down justifications, as results of divine or natural law, and took shape either as commitments towards something or someone supposed to be located above the citizens, or the subjects. Or, alternatively, as a form of paternalistic responsibility towards those individuals who were supposed to be depending on the authority holders. As a consequence, heteronomy was the rule, while autonomy as the condition in which individuals endowed with reason create themselves the norms they are bound to follow, has been developed rather recently. ${ }^{43}$ The idea of the community that gives rules to itself is the outcome of a parallel evolution both in political philosophy, on the one hand, as well as in real politics and law on the other. Starting with the legacy of political philosophy, autonomy emerged for the first time against heteronomy ${ }^{44}$ as the result of the paradigmatic revolution

\footnotetext{
${ }^{39}$ Supra Section B.I.

${ }^{40}$ Supra Section B.II.

${ }^{41}$ Infra Section C.I.

${ }^{42}$ Infra Section C.II.

${ }^{43}$ Regarding the distinction between the top-down legitimation of public power and its bottom-up counterpart, see HaNS Kelsen, Vom Wesen und Wert der Demokratie 64, 98. (Mohr 1929); Hans Kelsen, General Theory of Law and State 283 (Harvard Univ. Press 1949); 283; see Dellavalle, supra note 26, at 91-113.

${ }^{44}$ To some extent, autonomy was already present in the ancient world, in particular in the Greek poleis and in the Roman republic. Yet, it was limited by the belief that the citizens_-only a relatively small part of the inhabitants—had grounded their political bond not only, and maybe even not primarily, on their free will, but also on the myth of a shared origin.
} 
from a holistic to an individualistic understanding of social order. ${ }^{45}$ According to the holistic paradigm of order, all members of the society have their appropriate place, which is determined by natural or divine law, and have no right to contest this condition. Thus, authority is supposed to be natural, based on force, competence or destiny, or it is assumed to be God-given. In this strongly hierarchical system, all subjects are obliged to fulfill their tasks, not because they have taken it upon themselves as a consequence of a mutual agreement, but because they are ordered to do so by the natural and/or God-given authority. It was Thomas Hobbes who triggered the paradigmatic revolution in the middle of the seventeenth century by putting for the first time the individuals at the center of the social and political community. ${ }^{46}$ In his view, individuals are not members of natural communities, without any reasonable possibility to escape, but rational beings who can decide to which kind of societas civilis they want to belong. This decision is taken through the form of a contract, or pactum unionis, on the basis of which the fundamental law of the community is set and the institutions entrusted with its government are constituted. This essential assumption is the basis of the contract theory of state, from Hobbes's closest successors - starting with Locke and ending with Kant - to its more recent exponents including Rawls and Habermas. Though sometimes quite distant from the epistemological premises of the original approach, they nevertheless maintain the centrality of the individuals in their interpretation of the social bond.

In general, philosophical theory anticipates the steps later taken by politics and positive law. The history of the idea of the moral and legal community which should be created by an act of will of free and equal individuals delivers one of the few exceptions to this rule. In fact, this idea is not to be found for the first time in Hobbes's works, but in a short, very essential document of historical constitutionalism. Indeed, it was in the Mayflower Compact of 1620-issued, therefore, a generation before Hobbes's De Cive was published-that the fundamental features of a community made by free and equal individuals on the basis of consent were laid down for the first time. ${ }^{47}$ Regardless of the inescapable, but rather non-influent references to God and to the King of England at the beginning of the text, it is the assembly of those "whose names are underwriten," which "combine(s) ... [these presents] togeather into a civill body politick, for our better ordering \& preservation." On the basis of the covenant, which is agreed upon "by these presents solemnly \& mutually," the members of the community "enacte, constitute, and frame such just \& equall lawes, ordinances, acts, constitutions, \& offices."

The contents anticipated by the Mayflower Compact came to completion, a little more than one and a half century later, during the great Revolutions of the late eighteenth century that ushered a new era of human history. The overture was delivered by the Virginia Bill of Rights on the June $12,1776 .{ }^{48}$ The contents that were implicitly present in the Mayflower Compact became explicit in the Virginia Bill of Rights. Four elements characterize the societas civilis as the social and political community based on the free, mutual, and reflexive recognition of rights. First, all human beings are assumed to be free, equal and independent of predetermined hierarchies. ${ }^{49}$ Secondly, individual rights cannot be fully alienated through the establishment of the political community. ${ }^{50}$ Thirdly, public power originates from the reflexive and conscious will of those individuals who are united to form a people. ${ }^{51}$ Fourthly, and finally, the institutions established by the covenant that creates the political community have only the task to protect the rights of its

\footnotetext{
${ }^{45}$ See Dellavalle, supra note 24.

${ }^{46}$ Hobbes, supra note 25.

${ }^{47}$ MaYflower COMPACT (1620), https://liberalarts.utexas.edu/coretexts/_files/resources/texts/1620\%20Mayflower\% 20Compact.pdf.

${ }^{48}$ Virginia DeClaration of Rights (1776).

${ }^{49}$ Id. $\$ 1$.

${ }^{50} \mathrm{Id}$.

${ }^{51} I d . \$ 2$.
} 
members. ${ }^{52}$ The same contents were taken up in a more concise way, only three weeks later, in the Declaration of Independence of the United States of America:

We hold these truths to be self-evident, that all men are created equal, that they are endowed by their Creator with certain unalienable Rights, that among these are Life, Liberty and the pursuit of Happiness. That to secure these rights, Governments are instituted among Men, deriving their just powers from the consent of the governed-That whenever any Form of Government becomes destructive of these ends, it is the Right of the People to alter or to abolish it, and to institute new Government. ${ }^{53}$

The last chapter of this most splendid period of the history of political ideas was the Déclaration des droits de l'homme et du citoyen, which marked the beginning of the French Revolution. ${ }^{54}$ Once again, the same principles as in the former documents are reiterated and reinforced, respectively in Article $1,{ }^{55}$ Article $16,{ }^{56}$ Article $3,{ }^{57}$ and Article $2 .^{58}$

The recurrence of the same principles in all most essential documents of the revolutions that paved the way to modern republicanism proves how fundamental they have been for the development of the liberal democracies. Indeed, it is no exaggeration to say that the idea of the moral and political community consisting of free and equal individuals, who are able to assert their rights and recognize them to one another on the basis of rational arguments, represents the core of a political system in which the safeguard of human rights, popular sovereignty and the rule of law can find their best implementation. More concretely, the protection of human rights is nothing but the guarantee that the fundamental conditions of interaction within a community of free and equal are realized. Furthermore, democratic participation expresses the involvement of the members of the community in the decisions on common concerns. Finally, the rule of law is the warrant that the rules of interaction within the community are respected.

Having established that the community of the free and equal who are capable of claiming their entitlements and of acknowledging them to each other on the basis of arguments is the fundament of liberal democracy, a problem arises, however, as regards the introduction of responsibility. In fact, responsibility seems to identify obligations which lie outside the boundaries of that community in a twofold sense. First, some of the entitlements are not determined through mutual recognition; and, secondly, some addressees are not members of the community. As a result, the appeal to responsibility would pave the way to a use of practical reason which refrains from the reference to the self-reflexive community and, lastly, to autonomy. Indeed, some obligations are not rooted in reasonable claims reflexively made by the rights holders, but in the external judgement of agents who deem some addressees of their actions worthy of specific respect. Yet, are we not taking a dangerous step if we abandon one of the most central conceptual tenets of liberal democracies?

Furthermore, such a step would also imply a significant epistemological problem. Indeed, how can we determine which rights should be protected? Or, beyond the rights-centered approach,

\footnotetext{
${ }^{52} I d . \$ 3$.

${ }^{53}$ The Declaration of Independence (U.S. 1776).

${ }^{54}$ Déclaration des droits de l'homme et du citoyen (Fr. 1789).

55"Les hommes naissent et demeurent libres et égaux en droits" ("Men are born and remain free and equal in rights") (id. art. 1).

56“Toute société, dans laquelle la garantie des droits n'est pas assurée, ... n’a point de constitution” “"Any society in which the guarantee of rights is not assured, ... has no Constitution") (id. art. 16).

${ }^{57}$ "Le principe de toute souveraineté réside essentiellement dans la nation; nul corps, nul individu ne peut exercer d'autorité, qui n'en émane expressément" ("The principle of any sovereignty resides essentially in the Nation. No body, no individual may exercise any authority which does not proceed directly from the nation") (id. art. 3).

58"Le but de toute association politique est la conservation des droits naturels et imprescriptibles de l'homme" ("The goal of any political association is the conservation of the natural and imprescriptible rights of man") (id. art. 2).
} 
how can our obligations be specified? If we assume the perspective of the self-reflexive community of autonomous individuals, the question is easy to answer-it is all members of the community who claim their rights and, after a deliberative process based on mutual recognition, establishalong with their fellow citizens-which entitlements are worthy of protection. Yet, in cases in which responsibility is applied, some addressees of obligations cannot claim their rights, so that is up to the agent to decide what should be done. The interpretation implies that agents can take the so-called position of the privileged observer, or in other words, a standpoint from which-due to their alleged superior knowledge - they are assumed to be able to know from the outside what are the essential interests of those who are involved, but are not in the position to speak out on their needs. Such an understanding, however, always encourages a patronizing attitude and an opinionated overestimation of the competences of those who are in charge of authority. Against the fascination of social and political technocracy, we should never forget the old, but nevertheless always topical question-quis custodiet ipsos custodes? ${ }^{59}$ Or, who will guard the guards themselves?

\section{The Intrinsic Particularism of Responsibility}

One of the most fervent advocacies of responsibility was delivered by Max Weber in his speech on Politik als Beruf (Politics as a Vocation) of $1919 .{ }^{60}$ Once again, resorting to responsibility is opposed to the predominant individualism of modern moral philosophy. More concretely, Weber contrasts the ethics of responsibility (Verantwortungsethik) with the ethics of conviction (Gesinnungsethik). ${ }^{61}$ According to the latter, moral agents act on the basis of their personal persuasion as regards what is true and just, while in the first case moral agents are primarily focused on the consequences of their actions. The two attitudes do not exclude one another: individuals can act responsibly and follow their own convictions. Nonetheless, from Weber's perspective, the priority cannot but be either the one attitude or the other. If the moral agent prioritizes the consequences of her or his action, then her or his moral principles will be relevant only in case that they do not bring about results in contrasts with the teleological preferences and prudential choices. On the contrary, if she or he consider moral principles indisputable, then the collateral effects produced by the action are assumed to be significant only to the extent that they can be seen as implementation of the above-mentioned principles. Hence, any kind of reconciliation of the opposite understandings of responsibility, with a conception in sight in which both moral principles and factual consequences are properly taken into account, is substantially ruled out. ${ }^{62}$

If it is the Gesinnungsethik to dominate, no doubts can be raised that it is the individualism of modern philosophy that takes the lead. It was René Descartes who located for the first time the source of truth in the solipsistic mental processes of the individual. ${ }^{63}$ Descartes' analysis was concentrated on the use of theoretical reason, therefore on epistemology as the theory of knowledge. His epistemological individualism deeply influenced modern philosophy and was quickly extended-already by Thomas Hobbes - to questions concerning the practical use of reason, thus to moral, social, and political philosophy. Yet, while in Hobbes's early version of the theory of rational choice the individual decision on which action should be performed was still essentially

\footnotetext{
${ }^{59}$ Juvenal, Satire VI, 347-48, http://www.thelatinlibrary.com/juvenal/6.shtml.

${ }^{60}$ Max Weber, Politics as a Vocation, in The Vocation Lectures 32-94 (David Owen \& Tracy B. Strong eds., Rodney Livingstone trans., Hackett 2004).

${ }^{61} I d$. at 83 .

${ }^{62}$ The fact that the perspective of a reconciliation of Gesinnungsethik and Verantwortungsethik is discarded by Weber does not mean that it cannot be outlined, though. A possible solution consists in distinguishing between the "perfect communication community," with the implementation of moral principles at its core, and the "real communication community-i.e., the real society, in which due attention must be granted to what any action might bring about. See infra notes $77,82,85$, and accompanying text.

${ }^{63}$ René Descartes, Discours de la Méthode (French \& European Pubns 1965) (1637); René Descartes, Meditationes De Prima Philosophia (CreateSpace 2016) (1641); René Descartes, Principia Philosophiae (AbeBooks 2018) (1644).
} 
connected with the acquisition of evidences from the world outside, Kant's theory of morals gave to the Gesinnungsethik its most uncompromising expression. In Kant's categorical imperative, individuals need no other evidence to know what ought to be done but their own considerations based on the correct use of reason. ${ }^{64}$ In other words, it is the task of the mental processes of the individual to find out what is just and true. The universalistic scope of the duties which are determined through the mentalistic and solipsistic procedure is guaranteed by the fact that all healthy rational beings must come to the same conclusion.

It is not surprising that the Gesinnungsethik emerges as a product of modern thinking. In fact it is - no less than the idea of the moral and legal community based on autonomy-the result of the paradigmatic shift from holism to individualism. Hence, if the ethics of conviction is connected to individualism, then the consequence should be that the ethics of responsibility must be linked to holism. Indeed, responsibility needs-much more than conviction-a community of reference which enables the agents to calibrate their actions on the basis of its visible and evaluable outcomes. Put differently, in order to take the consequences of their actions into due account, agents must have the possibility to refer them to a definite, specific, and perceivable community. It is not by chance that responsibility has been, and still is, most commonly used with reference to the most immediately perceivable of all social communities, namely the family. Then, when it seemed to be useful or even necessary to extend the application of the concept to more inclusive social structures, the familistic interpretation of the polity introduced by Aristotle ${ }^{65}$ was expanded to the sovereign state. This was used to justify both the obedience of the subjects and, again, the responsibility of the monarch as an oversized pater familias. ${ }^{66}$ No less than the sovereign state, albeit differently, the idea of the nation was also built on the foundation of an assumed-and largely imagined ${ }^{67}$ - kinship, toward which every member of the national community had to feel responsible. ${ }^{68}$

Yet, if responsibility is so closely tied to the identification of a specific community of reference, then a significant difficulty arises when it comes to a possible application of the concept to morethan-particularistic contexts. Thus, the question is whether responsibility, in principle, is suitable to a universalistic approach. Regarding this point, a specific - and quite contradictory-position is taken by the relation between universalism and the sense of responsibility that may grow out of religious beliefs and affiliations. In fact, belonging to a religious community always entails not only an element of inclusion, but also the exclusion of those who are not members of that community. Nonetheless, all world religions contain in their holy texts some kind of exhortation to respect the others. Leaving this thorny question aside and concentrating on only the rational justification for the universalistic exercise of responsibility, a distinction should be made on whether the universalistic responsibility that we should put in place is to be applied only to the whole humankind, or also to the world of non-human entities. In both cases, the justification resorts to the holistic conceptual organon. Yet, the notions which are respectively employed differ to some extent. In the latter case, the holon is the ecosystem of the living creatures to which we belong to, so that the justification of responsibility consists in stressing our being part of the system in its entirety. ${ }^{69} \mathrm{On}$ the contrary, in the former case, the holon has a more limited range, so as to include exclusively our fellow humans. Two main strategies have been developed in order to defend the commitment to this more restricted understanding of the whole, which turn out to be, lastly, variants of the same assumption. In both circumstances, the goal consists of rationally justifying the existence of a

\footnotetext{
${ }^{64}$ Kant, Grundlegung zur Metaphysik der Sitten, supra note 16, at 49.

${ }^{65}$ Aristotle, Politics, Book I, Ch. 2, 1252b (Clarendon Press 1967).

${ }^{66}$ JeAn Bodin, Six LiVRes de LA RÉPUblique (LGF 1993) (1576).

${ }^{67}$ Benedict Anderson, Imagined Communities (Verso 2006). On the construction of the national community, see also John Breuilly, Nationalism and the State, (Manchester Univ. Press 1982); Ernest Gellner, Nations and Nationalism (Blackwell 1983); Eric J. Hobsbawm, Nation and Nationalism Since 1780 (Cambridge Univ. Press 1990).

${ }^{68}$ Adam Müller, Die Elemente der StaAtskunst (Fischer 1922) (1809).

${ }^{69}$ Arne Naess, Collected Works, in 21 The Trumpeter 2 (2005).
} 
universal community of humankind, to which everyone of us has to be held responsible. The first and older strategy points to the alleged universal sociability of human beings which drives us to build social groups. Because it is assumed here that this driving force is not confined by any border, the most inclusive community towards which we are responsible is the one which includes all fellow humans. This concept was first developed by the Stoics ${ }^{70}$ and then taken up by many important thinkers of Western modernity. ${ }^{71}$ More recently, it has been replaced by a second strategy, though springing itself from the same source. Contemporary international lawyers have justified the responsibility that we are assumed to owe to the whole humankind by resorting to the idea that a universal human community exists which would share the same values and interests. Or, because there is a humankind which is characterized by the same essential condition, we must act with responsibility towards the whole of it. ${ }^{72}$

Regardless of whether the holon is understood more or less narrowly, resorting to the holistic organon in order to justify universalistic responsibility always raises deep-going conceptual problems. The first affects both the more limited understanding of the holon as well as its more inclusive vision. In both cases, the fundament of responsibility is assumed to be a factum brutum, a mere being or an object which only needs to be detected, and not the result of discursive processes in which arguments are exchanged so as to identify the most correct use of the theoretical and practical reason. ${ }^{73}$ By grounding responsibility on something which is simply presupposed to be, we would presume that there is an objective and non-discursive truth-be it the homeostasis of the ecosystems or the universal community of values - which waits only to be discovered and asserted by the privileged observer. ${ }^{74}$ Once again, we would leave the field of the moral and legal community based on autonomy, thus switching almost necessarily to the belief that someone possesses a more qualified insight on what is worth being safeguarded. And, once more, the reply emerges as almost self-evident-why should we admit that someone holds a truth which lies beyond any contestation? Moreover, regarding the presumption of the existence of a community of humanity characterized by shared interests and values, a further problem is to be added.

\footnotetext{
${ }^{70}$ Johannes VON ARnim, StOICORUM Veterum Fragmenta (Teubneri 1905).

${ }^{71}$ Alberico Gentili, De jURE belli libri tres I, I, at 10, I, XV, at 107 (Clarendon Press 1933 (1588); Francisco Suarez, De legibus, ac Deo legislatore, in Selections from Three Works Book II, Chapter XIX (Clarendon Press 1944); Hugo Grotius, De Jure Belli ac Pacis Prolegomena 6, 16, 17 (William S. Hein \& Co. 1995) (1625); Samuel Pufendorf, De jure naturae et Gentium libri octo Book II, Ch. II, III, VII, XV, Book VIII, Ch. VI (William S. Hein \& Co., 1995) (1672); Christian WolfF, Institutiones JURIS NATURAE ET GENTIUM Book IX, Ch. I, V, VI (Nabu Press 2012) (1750).

${ }^{72}$ Hermann Mosler, The International Society as a Legal Community (Sijthoff \& Noorfhoff 1980); Christian Tomuschat, International Law: Ensuring the Survival of Mankind on the Eve of a New Century, in 281 COLLECTED Courses of The Hague Academy of International Law (Nijhoff 1999); Andreas L. Paulus, Die internationale

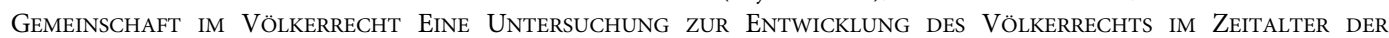
Globalisierung (Beck 2001); Mehrdad Payandeh, Internationales Gemeinschaftsrecht (Springer 2010).

${ }^{73}$ The search for the objective truth is a rather dismissed activity in the post-Wittgensteinian philosophy of knowledge. See Ludwig Wittgenstein, Philosophische Untersuchungen, in Werkausgabe (Suhrkamp 1984); Donald Davidson, Subjective, Intersubjective, Objective (Clarendon 2001); Donald Davidson, Problems of Rationality, (Clarendon 2004); Robert Brandom, Making It Explicit (Harvard Univ. Press 1998); JÜrgen Habermas, WAhrheit und ReChtFertigung (Suhrkamp 2004); Sergio Dellavalle, Law as a Linguistic Instrument without Truth Content? On the Epistemology of Koskenniemi's Understanding of Law, 77 ZEITSCHRIFT FÜR AUSLÄNDISCHES ÖFFENTLICHES RECHT UND VÖLKERRECHT, 199-233 (2017).

${ }^{74}$ Denying that discourse has essentially to be based on a truth that must simply be discovered by the privileged observer does not imply that the very same discourse can consistently refrain from any reference to objective truth. In fact, the reference of propositions to real situations or facts plays an indisputable role within a meaningful exchange of arguments. Yet, this component makes sense-according to a post-ontological and intersubjective understanding of knowledge-only insofar as it is integrated by the assumption of a commitment of all participants in the communication to fair-minded purposes and by their readiness to accept that their assertions have to meet the criteria for a general and mutual acknowledgement. In other words, truth can be acknowledged as such only to the extent that assertions that claim to be true are subjected to

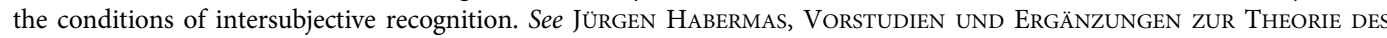
KOMMUNikativen Handelns 598 (Suhrkamp 1984); J. Habermas, NaChMetaphysisches Denken, 73, 105, 123 (Suhrkamp 1988) JÜrgen Habermas, WAHrheit UND ReChtFerTigung 110 (Suhrkamp 1999).
} 
While some facts seem to support this assumption, a no less significant amount of evidences speaks against it. In other words, the humankind is capable of shared solutions and solidarity, but also of selfishness and brutality, so that the existence of a universal community is rather to be regarded as a wish than as a matter of fact. Or it can also be seen as the attempt to ontologize what is a pragmatic-transcendental capacity of humans. In fact, we can communicate with one another and work out consensual solutions to shared problems. What is certain is the possibility of starting to exchange arguments; the result, instead, is always open and far from guaranteed.

\section{Toward a Cosmopolitan and Rights-Related Concept of Responsibility}

At the end of the inquiry carried out in the former Sections we come face-to-face with a dilemma. On the one hand, responsibility broadens the horizon of the use of practical reason and the domain of the addressees of obligations. According to this view, responsibility appears to be intuitively correct when compared to the rather limited range of the moral and legal community based on autonomy. On the other hand, however, the abandonment of the centrality of the moral and legal community grounded on self-rule has consequences which are anything but convincing. Furthermore, every attempt to justify the application of responsibility to universalistic contexts by resorting to some kind of holistic ontology is worryingly feeble. A possibility to overcome the stalemate is provided by the conceptual organon of the communicative paradigm of social order. ${ }^{75}$

This recent outcome of the paradigmatic revolution from the philosophy of modern subjectivism to intersubjectivity-also known as discourse theory-does not reject the legacy of individualism as radically as other contemporary post-unitary paradigms of order, like systems theory or postmodernism. ${ }^{76}$ Rather, it maintains one of its most essential tenets, namely the idea that the core of the social bond consists of the individuals with their endowment of reason and interests, and not of a predetermined vision of the common good, of self-reproducing functional systems, or of particularistic narrations. That being said, in contrast to modern individualismand also to Kant whose philosophy of universalistic rationalism is seen by the exponents of discourse theory as a direct inspiration - the communicative paradigm of order does not assume that true, or at least correct, results of the use of theoretical and practical reason can be achieved on the basis of solipsistic mental processes. In other words, it is not lone individuals who can find out what is true and just according to a correct use of their own rational capacities. Rather, the search for truth and justice is the task of intersubjective procedures of communication consisting in the exchange of arguments within the context of mutual recognition.

As a result of the procedures of argumentative interaction, a communication community is established which provides the epistemological foundation of what has been defined, in the former Sections, as the moral and legal community of the free and equal. In fact, the communication community recognizes rights and duties on the basis of claims expressed through meaningful propositions and their mutual acceptance. Yet, this is precisely the definition of obligations which is regarded as insufficient by the supporters of the introduction of the reference to responsibility. And, it is the concept of responsibility that should take on the task of expanding the concept of obligations so as to address issues which require our justifiable intervention. Therefore, the question is: can the idea of the communication community integrate in its conceptual framework the issues raised by the discourse on responsibility, specifically as regards the extension of the domain of the addressees of obligations as well as the need for more flexibility under specific

\footnotetext{
${ }^{75}$ Karl-Otto Apel, Transformation der Philosophie (Suhrkamp 1973); Karl-Otto Apel, Diskurs Und Verantwortung (Suhrkamp 1990); JÜrgen Habermas, TheOrie des KOMMUNiKativen Handelns (Suhrkamp 1981).

${ }^{76}$ Sergio Dellavalle, Addressing Diversity in Post-Unitary Theories of Order 1-28 (GlobalTrust Working Paper No. 05, 2015); Armin von Bogdandy \& Sergio Dellavalle, Universalism and Particularism: A Dichotomy to Read Theories on International Order, in System, Order, AND International Law 482-504 (Stefan Kadelbach, Thomas Kleinlein \& David Roth-Isigkeit eds., Oxford Univ. Press 2017).
} 
circumstances? Or, how can we extend obligations to children or impaired fellow humans, oppressed individuals and peoples, past or future generations, sentient non-human animals, the ecosystem, and the biosphere as a whole, without giving up the idea of the moral and legal community as based on rational individuals who are capable of mutual recognition? It is possible to respond positively to these challenges if we introduce a distinction between the real communication community and the ideal communication community. ${ }^{77}$ The former describes the factual social context in which arguments are exchanged. The latter indicates, instead, the most inclusive composition of the communication community, beyond the limitations of the real social contexts. We have to ascribe to the ideal communication community all beings whose claims can be reasonably considered overlapping or analogous to those explicitly expressed by the real participants in the argumentative interaction. In principle, therefore, it is possible to include into this community rational as well as non-rational beings, presently living individuals along with those who lived in the past or will live in the future, and persons who are able to express themselves in a propositional way as well as those who are not. This can be done, however, only under the condition that their claims are equivalent to those of the active members of the community of argumentative interaction. Because the discourse within the real communication community should always take all reasonable arguments into account, the real participants can achieve normatively acceptable solutions only if they always keep the situation and claims of all possible members of the ideal communication community in mind.

By shifting the focus from the real to the ideal communication community, the moral and legal community is expanded in space, time, composition, and contents. Against this conceptual background, it is necessary to specify under which conditions and to what extent those individuals - human or even non-human beings - which have been identified in the second Section as reasonable addressees of obligations and responsibility can be integrated into the communication community. Only then can they be regarded as members of the moral and legal community. A quite easy challenge is posed by children or by people affected by mental disease or dementia. ${ }^{78}$ In fact, even if they cannot express their claims in a propositional way, children are destined to become fully-fledged members of the moral and legal community in the future, while elderly patients with dementia have been part of it in the past. Furthermore, people with mental diseases could have been members in their own rights, if only some circumstances would have been less negative. Therefore, we can reasonably assume that their claims are analogous to those of the active participants in the communication community, if these only were in the same situation. In fact, no one can raise serious doubts on the membership of children and mentally impaired persons in the community of the rights holders and addressees of duties. A similar argument can also be applied to the obligations towards those who are hindered from participating in the discourse by political violence and social discrimination. ${ }^{79}$ In this case as well, the addressees of obligations can be presumed to have claims which are the same as those of the active members of the communication community in a comparable situation. Thus, the obligations which the active members of the moral and legal community have towards them do not come from some kind of undetermined responsibility; they are simply duties and so is the responsibility to protect, too, the restriction of which can be justified only if their fulfillment would imply an even greater danger for the protection of other rights.

While the argument of analogy can also apply to the obligations towards past and future generations, ${ }^{80}$ the question is more difficult when it comes to the situation of non-human animals. ${ }^{81}$ In their case, we cannot simply presuppose a similarity of claims because of the

\footnotetext{
${ }^{77}$ Apel, supra note 75, at 358, 434.

${ }^{78}$ Supra Section B.III.

${ }^{79}$ Supra Section B.IV.

${ }^{80}$ Supra Section B.VI.

${ }^{81}$ Supra Section B.V.
} 
interspecific barrier. Does a non-human animal have an interest to live? Or to be free? It is problematic for us to presume what they need because we cannot take on their position. Furthermore, there may be differences between species. There is at least one element, however, that we have in common with many non-human animals: the capacity to feel pain and to suffer. On the basis of this consideration, non-human animals can be included into the moral and legal community, at least in a non-reciprocal condition of moral patients and rights holders. ${ }^{82}$ But this inclusion must rest on the partial redefinition of the epistemological fundament of the communication community, which should not be confined to the level of the exchange of rational arguments. Rather, to include sentient beings, and also expand the range and meaning of communication, the exchange of rational arguments should be seen as the instrument to mutually avoid pain and suffering. On the contrary, no possibility is given to bring non-individual beings, such as the ecosystem of the world of living creatures as a whole, in the communication community. ${ }^{83}$ Their safeguard can nevertheless be justified as a duty towards those individuals whose right is recognized to enjoy the beauty of the world and decent living conditions also in the near and far future.

It is therefore possible, by slightly modifying the accentuation of the communication community, to include in the moral and legal community also those addressees of obligations who seemed to have to rely on the exercise of responsibility - and not on the fulfillment of duties-because of their apparent extraneity to the reason-based and autonomy-based pact of the free and equal. Yet, a problem arises here that should not be passed over in silence. In fact, what I am proposing to introduce implies the abandonment of the previous perfect correspondence between the status of rights holder and that of duties bearer, in the sense that some members of the moral and legal community may be regarded as rights holders without being duties bearers. As a consequence, what is the difference between an extended community of communication and the technocratic approach of the privileged observer? The difference depends on the point of view that is taken. In the case of the privileged observer, the point of view is that of the agent who is assumed to be in possession of information that the addressee of the action does not have or is not even able to understand and process. In the case of the extended community of communication, instead, the point of view is that of the potential addressee of the action. Because we do not know precisely which interests and claims addressees may have, due to the fact that they are actually incapable of participating in the communication, we are forced to formulate their interests in a putative way. Thus, the members of the community of communication commit themselves to extend their interests and claims so as to include the reasonable positions of those who are excluded. Therefore, no privileged observer is presumed-and no uncontested expert is needed-because the decision is not about some kind of implementation of an objective truth, but about the discursive clarification of the contents of an agreement which is based on the exchange of arguments. Simply, this exchange must be organized in a way that takes the position of all possible participants in the community of communication into account.

The dialectic between the real communication community, and its ideal counterpart, also accounts for that recourse to the concept of responsibility which points out its allegedly superior flexibility as regards the choice of the instruments of action. ${ }^{84}$ In the ideal communication community, duties would perfectly correspond to rights so that when a right is acknowledged, an immediate and uncompromising action should be implemented to protect it. Yet, we do not live in a perfect communication community, but only in a real one, in which sometimes a more prudential attitude is required. ${ }^{85}$ This means that, under certain circumstances, we are allowed to decide not to protect—at least not immediately and without compromise-right holders from the harm that is currently done to them. Nonetheless, the consequence should not be drawn that

\footnotetext{
${ }^{82}$ JÜRgen HABERMAS, ERLÄUtERUNGEN ZUR DiskURSEThiK, 219 (Suhrkamp 1991).

${ }^{83}$ Supra Section B.VII.

${ }^{84}$ Supra Section B.VIII.

${ }^{85}$ Apel, supra note 75, at 179.
} 
a duty to safeguard essential human rights has to be replaced by an arbitrary attitude, which we may call responsibility. The duty remains undiminished in its fundamental content, even if we have to acknowledge that its fulfillment in that specific situation would bring more harm than relief. Understood this way, refraining from action is not an alternative to the accomplishment of duties, based on a different, not deontological but strictly contextual approach. Rather, it may be sometimes justified, but only if action would bring even more damage to the safeguard of rights. Furthermore, compromises may be necessary in the real world-actually, we are not citizens of the civitas Dei, but rather of the civitas diaboli. Nonetheless, they are acceptable only to the condition that the concession leads to a middle- or long-term improvement of the protection of rights, and that the essential content of rights is not explicitly denied by our action or omission.

\section{E. Conclusion}

We can ask, now, what is left of the concept of responsibility if the purposes for which it was introduced can be achieved by resorting to a modified idea of the autonomous communication community based on mutual recognition. Indeed, nothing is left if the concept's task consisted in creating a space for subjective arbitrariness in the justifications of action. Based on the conceptual pattern that has been developed in this contribution, obligations with a relevant social impact cannot but be duties which correspond to mirror-inverted rights. ${ }^{86}$ Distinctions have to be made in this context-in the sense that we are allowed, under certain circumstances, to perform a duty with justifiable graduations of completeness. The distinctions, however, do not have any consequence for the conceptual core of a convincing theory on the correct use of practical reason. Does this mean that the notion of responsibility is useless and should be abandoned? The answer is not at all for at least three main reasons. The first is the reference to responsibility to describe obligations located in the private domain. The second, instead, is not private, but public. Even with regard to issues of public relevance, responsibility can be reasonably referred to in order to address obligations which do not correspond to claims explicitly made by rights holders. They are duties indeed, but duties of a specific kind insofar as they imply an extension of the autonomous communication community from the real to the ideal level. The third reason addresses the personal motivation of actions. Reasonable arguments tell us that obligations-at least in the public domain - are grounded in duties, but duties seem sometimes to be somehow cold and far away, so that we need a driving force which is closer to our deepest sentiments. And, this can be responsibility, as something which rests on a sincere feeling of attachment to the world. It may be duty, but it feels like love.

\footnotetext{
${ }^{86}$ The question may be different as regards personal obligations with a rather limited impact on common issues, such as obligations deriving from friendship. In these cases, we can feel obliged out of a sense of mutual responsibility and solidarity, which is, here, really outside the domain of duties.
} 